\title{
Chronic Kidney Disease-Related Mineral and Bone Disorders
}

\author{
Àngel Argilés ${ }^{\mathrm{a}}$ Raymond Vanholder ${ }^{\mathrm{b}}$ \\ ${ }^{a}$ RD-Néphrologie, Néphrologie Dialyse St. Guilhem and Groupe Rein et Hypertension EA3127, Institut Universitaire \\ de Recherche Clinique, Montpellier, France; ${ }^{b}$ Nephrology Section, Department of Internal Medicine, \\ University Hospital, Ghent, Belgium
}

\section{Key Words}

Bone disease $\cdot$ Chronic renal disease

\begin{abstract}
The clinical practice guidelines, their scope, limitations and applicability within the field of mineral and bone disorders have been analyzed. The different available guidelines have been compared and their content has been put into the perspective of the user. The aim has been to review their accuracy and relevance for the key set of mineral and bone disorders, and not to attempt to rewrite them or provide new guidelines based on the authors' feelings and experience.
\end{abstract}

Copyright $\odot 2009$ S. Karger AG, Basel

\section{Introduction}

\section{Aims and Willingness in Producing Guidelines}

Clinical practice guidelines (CPGs) in kidney disease have arisen from the willingness to help 'the busy practitioner' in making up diagnostic and therapeutic strategies from the overwhelming amount of available information. Information in guidelines is of variable reliability and objectivity, and it is not uncommon to observe a skewing influence driven by partners in health delivery that have conflicts of interest when advising diagnostic tools or treatment. We may find among the renal physicians' community, those who support the production of guidelines for some or all the aspects related to their practice and those who feel uncomfortable with the CPGs. The supporters claim that CPGs help in improving outcomes by harmonizing the targets of a treatment strategy and by proposing the therapeutic tools to achieve them. The detractors think that CPGs may limit the personal approach of the physician in healing patients and most likely prevent free progress in therapeutic innovation.

Before we proceed with the analysis of the clinical guidelines of the chronic kidney disease (CKD) and mineral bone disorders, we want to stress the importance of distinguishing CPGs from clinical practice recommendations (CPRs). CPGs often are largely based on expert opinion (which is not infrequently proven to be incorrect) rather than on evidence. CPRs should (ideally) always rest on high-grade evidence alone. If insufficient highgrade evidence is available, CPRs should not be issued. Confusion between CPGs and CPRs is rampant and has led to a lot of problems (including premature and unjustified public policymaking by government bodies). Premature codification of CPRs into public policy can have a damaging effect and can be very costly.

\section{Reference Quantification of Guidelines in Nephrology} and Cardiovascular Medicine as an Indicator of the

Interest in Guidelines

To get an idea of the place taken by guidelines in practicing renal medicine, we performed a simple inquiry via Medline. We introduced a few words stepwise to define

\section{KARGER}

Fax +4161306 1234

E-Mail karger@karger.ch

www.karger.com (c) 2009 S. Karger AG, Basel

$1660-2110 / 09 / 1123-0128 \$ 26.00 / 0$

Accessible online at:

www.karger.com/nec
Àngel Argilés

RD-Néphrologie, 104, rue de la Galéra

FR-34090 Montpellier (France)

Tel. +33 46774 2070, Fax +33467535138

E-Mail Angel.Argiles@inserm.fr 
Table 1. Number of citations on the topic on April 5, 2008

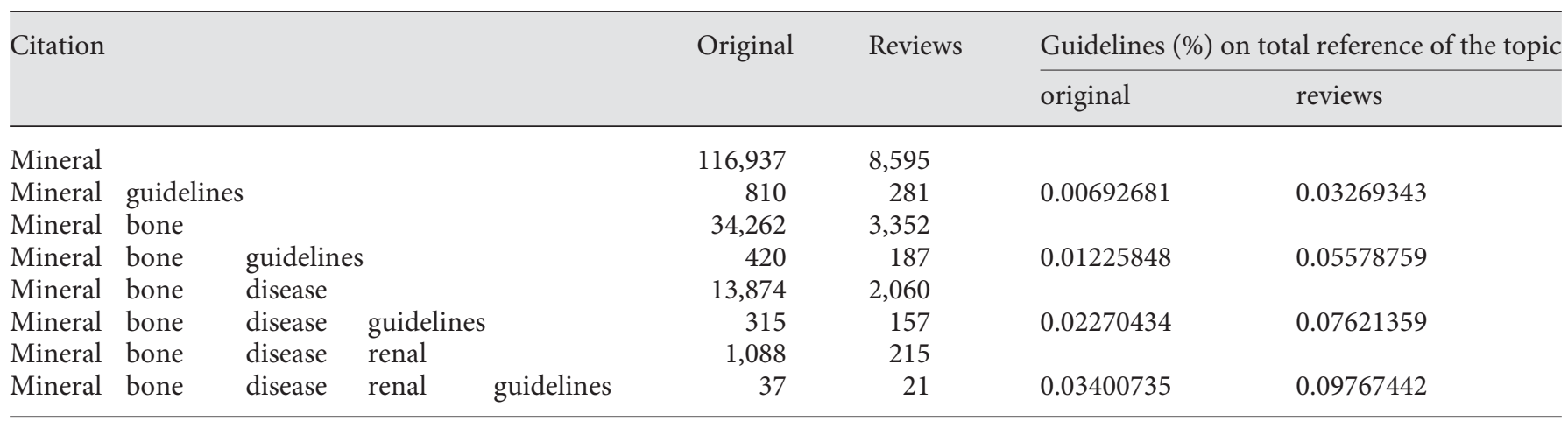

Table 2. Comparison of the number of citations related to guidelines between renal medicine and cardiology

\begin{tabular}{lrrrrr}
\hline Citation & Original & \multirow{2}{*}{ Reviews } & \multicolumn{2}{l}{ Guidelines (\%) on total reference of the topic } \\
\cline { 5 - 5 } & & & original & reviews \\
\hline Cardiac disease & 682,795 & 76,584 & & \\
Cardiac & disease guidelines & 9,299 & 3,274 & 0.01361902 & 0.04275044 \\
Renal disease & 330,991 & 41,741 & & \\
Renal disease guidelines & 3,003 & 1,174 & 0.00907275 & 0.02812582 \\
Comparison renal/cardiac & & & 0.66618252 & 0.65790717 \\
\hline
\end{tabular}

CKD-MBD. The keywords were: 'mineral' - 'bone' - 'disease' - 'renal'. At each step the keyword 'guidelines' was added. The results of these queries are given in table 1 . It can be observed that $0.7 \%$ of the original articles selected under the keyword 'mineral' are also kept when adding 'guidelines'. The percentage of published articles related to guidelines increases as the topic is more defined, so that $3.4 \%$ of the 1,088 original articles selected with ' $\mathrm{min}$ eral' 'bone' 'disease' 'renal' keywords are also kept when adding 'guidelines'.

A second point we wanted to estimate was whether the interest on CPGs is particular to renal medicine. When using the keywords 'cardiac' - 'disease' and added 'guidelines', we obtained $1.3 \%$ of the original papers related to guidelines. Whereas using 'renal' - 'disease' and adding 'guidelines', the proportion of references related to guidelines was substantially less $(0.9 \%)$, which represents twothirds of what is observed in cardiology (table 2).

One could conclude that first, writing, proposing and commenting CPGs is more and more frequent as the area of the disease is more restricted and defined. Second, CPGs are not confined to CKD, being more prominent in cardiac medicine, suggesting either that cardiologists are ahead of nephrologists in harmonizing their diagnostic and therapeutic approaches to heart disease, or renal disease is simpler to harmonize and does not need that investment. If the former is true, the CPGs supporters could expect a happy time to come, while if the latter holds true, the skeptical will finally see the end of the constraints to their clinical freedom.

The costs of making CPGs are high, both in financial and also personal aspects. An enormous effort has been and still is made by the national and international societies endorsing these initiatives. However, beyond this societal effort, to really make the CPGs requires the personal investment of a large number of panelists, usually selected on the basis of their clinical experience and recognition (thus, already overloaded by work), in a demanding, time-consuming new task that interferes for most of them with the maintenance of the level of practice that has made them experts. If this process was to last too long, one might end by having a group of physicians telling what to do to the community, while the latter in the mean time would have acquired more experience than the 'experts' they are supposed to obey. 
Finally, suspicion may remain as to the real beneficiaries. Are these the patients, or a few companies that shield themselves behind the guideline labeling? The policy adopted by KDIGO and ERA-EDTA aiming to avoid sponsorship of specific guidelines by directly interested industries is timely [1]. Application of GRADE, or any other tool for evidence grading as proposed by KDIGO, allows appropriate benefit/harm balance analyses for a series of clinical situations [2]. This approach has gained support from several initiatives (CARI, UK Renal Association, ERA-EDTA, CSN, K/DOQI), and it will certainly help in the production and acceptance of the CPGs. The key point is to separate the financing of the development of CPGs/ CPRs and the actual process of identifying the need for a guideline. The National Institute for Clinical Excellence (NICE) in the UK has done a good job of keeping commercial support separate from the development of CPGs/ CPRs. Agencies which accept direct financing for CPGs/ CPRs development are more suspect and risk losing their credibility in the CPG/CPR 'marketplace'.

\section{Methods in Producing Guidelines}

The methods to produce the CPGs are crucial and all the efforts aiming to guarantee objectiveness and transparency will be rewarding in terms of acceptance and use. The steps described by the KDIGO initiative include: Prioritization of problems and definition of key questions to be addressed; selection of guideline group, agreement on group processes; systematic review; preparation of evidence profiles; grading the quality of evidence for each clinically important outcome; weighing relative importance of each outcome; grading the overall quality of evidence across all important outcomes; balance of benefits and harms; review of other considerations, including costs, in addition to net health benefit and quality of the evidence; formulation of a guideline recommendation and grading the strength of the recommendation based on the level of confidence, that adherence will do more good than harm [2]. Despite all these recommendations in the production of the guidelines, some have flagrantly conflated association with causation, often in an unjustified and uncritical manner.

\section{Evaluation of the CPGs}

The CPGs have to be achievable and the practitioners have to appropriate them and share their rationales. These are prerequisites for the implementation of CPGs. Although one might have the impression that adherence is increasing, there are no proper data supporting this supposition. The consequences of adhering, or not adhering, have only recently been reported.

\section{What Is Available?}

The most utilized guidelines for the treatment of CKD-mineral bone disease (MBD) are from the Kidney Disease Outcomes Quality Initiative (K/DOQI) [3] of the National Kidney Foundation (National Kidney Foundation-K/DOQI CPGs). They were published in 2003. Other supranational initiatives include the kidney disease improving global outcomes (KDIGO), established in 2003 as an independently incorporated non-profit foundation governed by an international board with the stated mission to 'improve the care and outcomes of kidney disease patients worldwide by promoting coordination, collaboration, and integration of initiatives to develop and implement clinical practices guidelines' (http://www. kdigo.org/), as well as the European Best Practice Guidelines (EBPG). Finally, different national societies of nephrology have also promoted the use of their guidelines: among them, Australia (Caring for Australians with Renal Impairment (CARI) CPGs), Canada (http://www. csnscn.ca/english/professional\%20practice/guidelines/ default.asp?s=1), United Kingdom (United Kingdom Renal Association, UKRA; UK Renal Association CPGs), Spain(http://www.senefro.org/modules/subsection/files/ guias_mom.pdf?check_idfile=2871), and Japan (http:// sciencelinks.jp/j-east/journal/J/Z0142A/2005.php).

CARI, EBPG, European Expert Panel (not operating under the EBPG), K/DOQI, UKRA and SEN (Sociedad Española de Nefrologia) have proposed guidelines for patients with stage $5 \mathrm{CKD}$ and in dialysis. Only the European Panel, K/DOQI, the UKRA and CARI give specific suggestions for clinical use for patients with stage 3 and 4 renal failure. The report of the SEN adopts the K/DOQI CPGs and proposes algorithms for treatment of MBD in CKD, very much in the way of those proposed by ERAEDTA (http://ndt.oxfordjournals.org/cgi/reprint/15/suppl_5/51.pdf).

The summary of the guidelines on $\mathrm{Ca}, \mathrm{P}, \mathrm{Ca} \times \mathrm{P}$ product and PTH of EBPG and non-EBPG European CPGs, as well as CARI, K/DOQI and UK Renal Association is provided in table 3 . This table has been built following the same structure as the report by KDIGO [4] and updated with the recent CARI and UK CPGs.

\section{Critique and Comparison of the Guidelines}

The CPGs on serum Ca level are quite uniform across the different societies and initiatives. The lower limit is 
Table 3. Summary of the available CPGs on CKD-MBD

\begin{tabular}{|c|c|c|c|c|c|c|}
\hline Origin & Year & $\mathrm{Ca}$ & $\mathrm{P}$ & $\mathrm{Ca} \times \mathrm{P}$ & PTH & Evidence \\
\hline \multicolumn{7}{|c|}{ CKD stage 3 and 4 (GFR from 30 to 50 and from 15 to $29 \mathrm{ml} / \mathrm{min} / 1.73 \mathrm{~m}^{2}$ ) } \\
\hline Europe (non-EBPG) & 2001 & $8.8-11.0 \mathrm{mg} / \mathrm{dl}$ & $2.5-4.6 \mathrm{mg} / \mathrm{dl}$ & - & $85-170 \mathrm{pg} / \mathrm{ml}$ & opinion \\
\hline K/DOQI & 2003 & $8.4-9.5 \mathrm{mg} / \mathrm{dl}$ & $2.7-4.6 \mathrm{mg} / \mathrm{dl}$ & $<55 \mathrm{mg}^{2} / \mathrm{dl}^{2}$ & 35 or $70-110 \mathrm{pg} / \mathrm{ml}$ & P: Ev, opinion \\
\hline CARI & $\begin{array}{l}2006 \text { prev. } \\
\text { rep. } 2000\end{array}$ & $8.8-10.4 \mathrm{mg} / \mathrm{dl}$ & $<6.8$ & $<71.9 \mathrm{mg}^{2} / \mathrm{dl}^{2}$ & $\begin{array}{l}2-3 \times \operatorname{limit} \\
(110-165 \mathrm{pg} / \mathrm{ml})\end{array}$ & Ca: Ev \\
\hline Renal Assoc. UK & 2007 & $8.8-10 \mathrm{mg} / \mathrm{dl}$ & $2.8-4.7 \mathrm{mg} / \mathrm{dl}$ & $\begin{array}{l}<60 \mathrm{mg}^{2} / \mathrm{dl}^{2} \\
\text { ideally } \\
<52 \mathrm{mg}^{2} / \mathrm{dl}^{2}\end{array}$ & $110-220 \mathrm{pg} / \mathrm{ml}$ & PTH: opinion \\
\hline \multicolumn{7}{|c|}{ CKD stage $5\left(G F R<15 \mathrm{ml} / \mathrm{min} / 1.73 \mathrm{~m}^{2}\right.$ or renal replacement therapy $)$} \\
\hline Europe $^{\mathrm{b}}$ & 2001 & $8.8-11.0 \mathrm{mg} / \mathrm{dl}$ & $2.5-4.6 \mathrm{mg} / \mathrm{dl}$ & - & $85-170 \mathrm{pg} / \mathrm{ml}$ & $\mathrm{B}$ \\
\hline $\mathrm{EBPG}^{\mathrm{c}}$ & 2002 & - & $2.5-5.5 \mathrm{mg} / \mathrm{dl}$ & $<55 \mathrm{mg}^{2} / \mathrm{dl}^{2}$ & - & P, PTH: opinion \\
\hline K/DOQI & 2003 & $\begin{array}{l}<10.2 \text { pref. } \\
8.4-9.5 \mathrm{mg} / \mathrm{dl}\end{array}$ & $3.5-5.5 \mathrm{mg} / \mathrm{dl}$ & $<55 \mathrm{mg}^{2} / \mathrm{dl}^{2}$ & $150-300 \mathrm{pg} / \mathrm{ml}$ & $\begin{array}{l}\text { Ca: opinion } \\
\text { B }\end{array}$ \\
\hline CARI & $\begin{array}{l}2006 \text { prev. } \\
\text { rep. } 2000\end{array}$ & $\begin{array}{l}8.4-9.6 \mathrm{mg} / \mathrm{dl} \\
\text { former } \\
(8.8-10.4)\end{array}$ & $\begin{array}{l}2.48-4.96 \mathrm{mg} / \mathrm{dl} \\
\text { (former } 6.8 \text { ) } \\
\text { pref. }<5.6 \mathrm{mg} / \mathrm{dl}\end{array}$ & $\begin{array}{l}<50 \mathrm{mg}^{2} / \mathrm{dl}^{2} \\
\text { former } \\
71.9 \mathrm{mg}^{2} / \mathrm{dl}^{2} \\
-\end{array}$ & $\begin{array}{l}2-3 \times \operatorname{limit} \\
(110-165 \mathrm{pg} / \mathrm{ml})\end{array}$ & opinion \\
\hline UK & 2007 & $8.8-10 \mathrm{mg} / \mathrm{dl}$ & $3.4-5.6 \mathrm{mg} / \mathrm{dl}$ & $\begin{array}{l}<60 \mathrm{mg}^{2} / \mathrm{dl}^{2} \\
\text { ideally } \\
<52 \mathrm{mg}^{2} / \mathrm{dl}^{2}\end{array}$ & $\begin{array}{l}<4 \times \operatorname{limit} \\
(110-220 \mathrm{pg} / \mathrm{ml})\end{array}$ & \\
\hline
\end{tabular}

Ev = Evidence; B = level of evidence (B): Consistent retrospective cohort, exploratory cohort, ecological study, outcome research, case-control study, or extrapolations from level A studies.

a Staging of CKD as adhered to by K/DOQI and KDIGO.

${ }^{\mathrm{b}}$ European recommendations based on clinical algorithms developed by a European expert panel not operating under EBPG.

${ }^{\mathrm{c}}$ Hemodialysis guidelines, section VII - Vascular disease and risk factors.

between 8.4 and $8.8 \mathrm{mg} / \mathrm{dl}$ both in stage 3 and 4 patients and in stage 5 patients and those treated with dialysis. The upper advised limit for serum Ca varies from 9.5 to $11 \mathrm{mg} / \mathrm{dl}$. It is interesting to note that the older recommendations tend to give higher serum Ca levels, such as the European non-EBPG published in 2001 proposing up to $11 \mathrm{mg} / \mathrm{dl}$ of serum Ca level. The CARI CPGs that proposed a range between 8.8 and $10.4 \mathrm{mg} / \mathrm{dl}$ in 2000 now propose a lower range of serum $\mathrm{Ca}(8.4-9.6 \mathrm{mg} / \mathrm{dl})$. However, both ranges given for patients with stage 3 and 4 as well as patients with stage $5 \mathrm{CKD}$ represent only opinion as evidence level. It is noteworthy that the same crosssectional observational studies that have identified serum phosphate as an increased mortality factor did not link serum Ca to increased mortality [5] (see below).

With the exception of the first CARI guidelines (2000), all the others propose to maintain serum phosphate levels lower than $5.5 \mathrm{mg} / \mathrm{dl}$ and non-EBPG European and
$\mathrm{K} / \mathrm{DOQI}$ propose $4.6 \mathrm{mg} / \mathrm{dl}$ as the upper acceptable limit in CKD 3-4 patients. Of note is that the reviewed CARI CPGs propose $4.96 \mathrm{mg} / \mathrm{dl}$ where formerly $6.8 \mathrm{mg} / \mathrm{dl}$ was proposed. The upper limit of acceptable serum phosphate level is different between renal failure stage 3 and 4 , and that allowed to dialysis patients. However, these recommendations that have a level of evidence level III for the population in dialysis are only opinion-based for the other stages of renal failure. The first work showing an association between mortality and hyperphosphatemia came from the studies of the US Renal Data System (USRDS) [5]. Following the USRDS reports, a strong association between hyperphosphatemia and mortality has been consistently observed. Ganesh et al. [6] reported data showing that levels of phosphate $>6.5 \mathrm{mg} / \mathrm{dl}$ result in a significant increase in mortality risk of any cause in dialysis patients (RR 1.21). 
The $\mathrm{Ca} \times \mathrm{P}$ product has also been proposed to influence the mortality risk of renal patients. In the same paper by Ganesh et al. [6] an increase in mortality of $6 \%$ per $10 \mathrm{mg}^{2} / \mathrm{dl}^{2}$ for $\mathrm{Ca} \times \mathrm{P}$ was reported. The range of the advisable upper limit of serum $\mathrm{Ca} \times \mathrm{P}$ product is quite variable depending on the issuing body (from 52 to $71.9 \mathrm{mg}^{2}$ / $\mathrm{dl}^{2}$ ) with the more recent CPGs proposing stricter targets, even though there is increasing evidence showing that $\mathrm{Ca} \times \mathrm{P}$ is not the key factor indicating the likelihood of calcification of soft tissues. The use of $\mathrm{Ca} \times \mathrm{P}$ is actively discouraged by some [7].

CPG recommendations on the serum levels of PTH are among the most variable thresholds in CKD-MBD. These levels have been presented in absolute values or in fold increase of the upper normal range. The latter approach was introduced to avoid confusion linked to the different assays presently available to determine serum PTH [8]. Most of the CPGs have considered the secondgeneration assays to determine serum levels of PTH, socalled intact PTH (iPTH) which measures both the entire $1-84$ as well as the N-terminal proteolysed PTH. This point is of importance since it is becoming clear that the different fragments of PTH may act through different receptors and may even induce opposite effects on the target cells [9]. The third-generation assays are becoming more widely used in clinical practice, and future CPGs will have to take this into account.

The lower limit proposed by the different initiatives varies between 35 and $85 \mathrm{pg} / \mathrm{ml}$ for patients with stage 3 and $4 \mathrm{CKD}$. For stage 5 patients and treated by dialysis, the lower advisable limit of PTH is between 2- and 3 -fold the upper limit of normal $(85-150 \mathrm{pg} / \mathrm{ml})$. Although such a high lower advisable limit of PTH is supposed to prevent the appearance of low remodeling bone disease, the evidence for such an advice is debatable. As commented by Monge et al. [10], the NKF meta-analysis on bone histomorphometry established $60 \mathrm{pg} / \mathrm{ml}$ as the best threshold to predict adynamic bone disease [11]. Further, mortality has been demonstrated not to increase in the patients included in the USRDS reports having PTH $<150$ $\mathrm{pg} / \mathrm{ml}[11]$.

The upper limit of the advisable range for serum PTH level varies from 110 to $220 \mathrm{pg} / \mathrm{ml}$ for the patients with stage 3 or $4 \mathrm{CKD}$ and up to 300 for the patients treated with dialysis. It is of note that the K/DOQI CPGs propose the highest serum PTH levels (165-300 pg/ml), although Block et al. [11] showed that between 300 and $600 \mathrm{pg} / \mathrm{ml}$ there is no increase of mortality in USRDS patients, this being confined to the group of patients with iPTH levels $>600 \mathrm{pg} / \mathrm{ml}$.
In addition to the principal markers of CKD-MBD (Ca, P, Ca $\times \mathrm{P}$ and PTH) the CPGs also propose how best to achieve the proposed target ranges. Particularly point 5.5 of the K/DOQI CPGs states that 'the total dose of elemental Ca provided by the Ca-based phosphate binders should not exceed $1,500 \mathrm{mg} / \mathrm{day}$, and the total intake of elemental $\mathrm{Ca}$ (including dietary $\mathrm{Ca}$ ) should not exceed $2,000 \mathrm{mg} /$ day'. This assertion is opinion-based and has obvious consequences for the patients, prescribers, pharmaceutical industry and reimbursers. It remains controversial $[10,12]$.

Guidelines are frequently rendered obsolete by new evidence. For example, Block et al. [13] in a post-hoc analysis involving 127 incident dialysis patients observed that mortality was lower in subjects randomized to sevelamer (5.3/100 patient-years, confidence interval (CI) 2.2-8.5) than in those randomized to Ca-containing binders (10.6/100 patient-years, CI 6.3-14.9; p = 0.05). Recent work by Suki et al. [14] failed to demonstrate a beneficial effect of Ca-free phosphate binders on survival of an overall group of prevalent dialysis patients followed prospectively although a significant effect was observed in a restricted subpopulation with a high mortality rate (patients $>65$ years of age) [14]. This would represent level of evidence level II (controlled prospective study) arguing against involving Ca-containing phosphate binders as contributors to increased mortality in prevalent dialysis patients. Indeed, Tonelli et al. [15], performing the metaanalysis of 14 primary publications of randomized trials (totaling 3,193 patients) found no evidence that sevelamer reduced all-cause mortality, cardiovascular mortality, the frequency of symptomatic bone disease or health-related quality of life [15].

Point 7 of K/DOQI CPGs deals with the supplementation of vitamin $\mathrm{D}$ treatment and gives a schematic for vitamin D supplementation which is only opinion based. Again, the consequences of advising one vitamin $\mathrm{D}$ derivative or another may be quite important and should ideally be based on controlled prospective studies. However, most of the time, those are not available. In that case, it might be useful that guidelines which lack evidence are clearly separated from real evidence-based recommendations, to avoid confusing the readership [1].

Guideline 9 states that dialysate $\mathrm{Ca}$ concentration should be $1.25 \mathrm{~mm}$ both for peritoneal dialysis and hemodialysis, and it is an opinion level of evidence. These points have also been challenged by the group of Fournier [10]. Fournier et al. $[16,17]$ were the first in identifying the increase in secondary hyperparathyroidism when using low dialysate $\mathrm{Ca}$. We have previously assessed the 
kinetics and the mass transfer of Ca during the dialysis session both using hemodialysis and online hemodiafiltration $[18,19]$. We implemented low dialysate $\mathrm{Ca}$ and $\mathrm{CaCO}_{3}$ to control hyperphosphatemia. We observed that using $1.25 \mathrm{mM}$ dialysate $\mathrm{Ca}$ concentration resulted in a significant increase of PTH as compared with the group using $1.5 \mathrm{~mm}$ dialysate $\mathrm{Ca}$, at 1 year of treatment [18]. Acute studies during dialysis demonstrated the lack of inhibition in PTH when using $1.25 \mathrm{~mm} \mathrm{Ca}$ and explained at least in part the increase in serum levels of PTH. Dialysis with $1.5 \mathrm{mM}$ Ca dialysate results in a nil Ca balance in the patients arriving to dialysis with a normal Ca level, whilst dialysis with a $1.25-\mathrm{mM} \mathrm{Ca}$ content results in a negative Ca balance [19]. Spasovski et al. [20] in a randomized controlled study comparing 1.25 vs. $1.75 \mathrm{~mm}$ dialysate Ca observed improved markers of bone remodeling in a group of dialysis patients with biological adynamic bone disease. This remains an area of controversy [21]. Calcimimetics, although not included in the original K/DOQI guidelines, are of use in achieving biochemical targets [22, 23], but their effects on Ca balance are largely unknown.

Guideline 10 of the K/DOQI on $\beta_{2}$-microglobulin amyloidosis does not recommend screening. Although based on opinion level of evidence, the guidelines state that at the evidence level no currently available therapy (except kidney transplantation) can stop $\beta_{2}$-microglobulin amyloidosis progression. It is courageous advice that does not conform with current practice in many centers, and that is based onto the lack of predictive value of the serum level of $\beta_{2}$-microglobulin for development of amyloidosis [24].

Concerning the type of membranes to use, the guidelines could have been even more cautious. First, the most cited paper constituting evidence showing that non-cellulosic membranes would protect from amyloidosis when compared to cuprophane is that of van Ypersele de Strihou et al. [25]. In that retrospective study the mean follow-up of the AN69 group was shorter than that of the cuprophane group and did not reach the mean elapsed time from dialysis onset to diagnosis of amyloidosis observed in the cuprophane group. Second, although also in a retrospective study, Schwalbe et al. [26] showed a decrease in the incidence of $\beta_{2}$-microglobulin amyloidosis that the authors did not attribute to the use of high-flux membranes, but rather to other factors such as the improvement in the water quality [26].

Cheung et al. [27] in a re-analysis of the HEMO study data reported that mean cumulative predialysis serum $\beta_{2}$-microglobulin levels but not dialyzer $\beta_{2}$-microglobu- lin clearance were associated with all-cause mortality in time-dependent Cox regression models [27].

It is obviously a sensitive point as it has direct financial implications. However, strong evidence supporting the use of high-flux membranes in preventing or handling $\beta_{2}$-microglobulin amyloidosis or in outcome is still needed.

\section{Evaluation of the CPGs}

Do We Follow the Guidelines and Meet the Proposed Ranges? And if Not, What Happens? If Yes, Is It Really Good?

The first point is to know whether we are able to fit the chemistries of our patients within the range of CPGs. However, this should not be the final aim. What we are looking for is to reduce mortality and improve survival and well-being of the renal patients. Therefore, two questions arise from the first one: (1) Is it harmful to maintain the patients out of CPG range? (2) Is it beneficial to correct and maintain the patients within $\mathrm{CPG}$ range?

Do We Follow the Proposed Guidelines and Meet the Proposed Ranges?

Adherence to K/DOQI practice guidelines for mineral and bone disorders has been recently evaluated [28] using administrative claims and laboratory data in a cohort of 793 patients requiring to have, within 90 days of each other, both a claim categorization for CKD and an eGFR $<60 \mathrm{ml} / \mathrm{min}$. It was observed that $91 \%$ of the patients having stage $3 \mathrm{CKD}$ had an appropriate serum Ca screening. Only $64 \%$ of those patients with stage 4 CKD were tested for MBD markers $\mathrm{Ca}$ and $\mathrm{P}$, as proposed by the K/DOQI guidelines. Fewer than $50 \%$ of the patients had PTH serum levels within the target range. The authors concluded that there remains substantial opportunity to improve. However, it may also well be that physicians do not adhere to the range of PTH proposed by the CPGs. As we have previously commented, the CPGs on serum levels of $\mathrm{PTH}$ are given on opinion-based data and are the most variable parameter among the different CPG sources.

The Netherlands Cooperative Study on the Adequacy of Dialysis (NECOSAD) [29] is a prospective study on incident patients over a 5 -year period. It shows that at 3 months of initiating dialysis, $40 \%$ of hemodialysis patients had serum Ca levels and 39\% had serum phosphate levels at the range of $\mathrm{K} / \mathrm{DOQI}$. This percentage decreased for serum Ca to $16 \%$ at 5 years. More than $50 \%$ of the patients had iPTH levels under the range proposed by K/DOQI. 
Combining the four targets $(\mathrm{Ca}, \mathrm{P}, \mathrm{Ca} \times \mathrm{P}$ and $\mathrm{iPTH})$ retained only $4.7 \%$ of the patients being within the four ranges after 3 months of dialysis treatment. The study of the Province of Ciudad Real [30] on prevalent dialysis patients having been treated $>3$ months during 2004 found $46.2 \%$ of the patients out of range for serum $\mathrm{Ca}, 42.8 \%$ for phosphate, $28.3 \%$ for $\mathrm{Ca} \times \mathrm{P}$ product and $68.8 \%$ for $\mathrm{iPTH}$. The group of patients with higher iPTH levels had a higher percentage of patients with hyperphosphatemia.

Another report coming from Spain compared the percentage of patients being within range for $\mathrm{Ca}, \mathrm{P}, \mathrm{Ca} \times \mathrm{P}$ as well as iPTH, before and after applying the CKD-K/ DOQI CPGs [31]. The authors studied three different dialysis units and observed that application of the CPGs resulted in an increased number of patients within range. They were $6.6 \%$ before and increased to $10.9 \%$ afterwards. It is noteworthy that although the improvement is statistically significant, the final figures remain insufficient. The same group found adherence easier with the introduction of cinacalcet in HPTH $-64.7 \%$ had all four parameters within range [23].

Craver et al. [32] studied 1,836 patients admitted in two outpatient nephrology units (from Lleida and Vizcaya): the number of patients with the values within the range of K/DOQI for Ca was $90.7 \%$ in stage $3 \mathrm{CKD}$ and decreased to $55 \%$ in stage 5 . For phosphate it went from 90 to $70.3 \%$, for $\mathrm{Ca} \times \mathrm{P}$ product from 99.9 to $83.8 \%$, and for iPTH it was $42.4,24.6$ and $46 \%$ for patients in stages 3,4 and 5, respectively. The percentage of patients having the four markers within range was 34.9, 18.4 and 21.6, respectively.

The success in following CKD-MBD CPGs on monitoring the follow-up and treating the patients is quite variable but generally low (5-22\%). Awareness and sensitization to the interest in following them is already starting to increase the numbers of patients within the advised ranges of the different markers of MBD, as reported by Wald et al. [33]. They observed a modest improvement in the number of patients within the CPG range during the first year after releasing the NKF-K/DOQI CPGs in Ca, $\mathrm{P}$ and $\mathrm{Ca} \times \mathrm{P}$ product. The improvement was not $\mathrm{ob}-$ served on the PTH serum level as the proportion of patients below the lower limit $(150 \mathrm{pg} / \mathrm{ml})$ significantly increased [33]. Again these results bring into question whether the lower limit proposed by K/DOQI for PTH is adapted to clinical reality. It rather suggests that when improving the number of patients with controlled $\mathrm{Ca}$ and $P$ levels, secondary hyperparathyroidism improves and iPTH serum level tend to decrease towards normal in the majority of cases. This would increase the proportion of patients at risk of developing adynamic bone disease considering solely the serum iPTH level.

\section{Is It Harmful to Maintain the Patients out of the CPG Range?}

This question may have a more direct answer for those variables known to be related to mortality, such as hemoglobin or serum albumin levels, although even for those parameters knowledge is scanty and new information appears continually [34]. The answer to this question may be even less clear for the so-called non-traditional risk factors such as those envisaged in the CPGs for CKD-MBD.

Survival analysis of the NECOSAD Study [29], based on the 3 months after initiating the dialysis time point, found no effect of out of range plasma concentrations of $\mathrm{Ca}$ and $\mathrm{P}$ on unadjusted mortality, suggesting that, if any effect on mortality, this would be less than that induced by the variables used to adjust (traditional risk factors).

Low Ca was associated with a hazard ratio (HR) of mortality of 1.7. No increased mortality was associated with high serum levels of Ca. In the same study, the survival analyses using a time-dependent Cox regression model retained an effect for high phosphate (HR 1.4 and 1.6 for HD and PD patients, respectively), and interestingly, no effect for high Ca or iPTH levels [29].

\section{Is It Beneficial to Correct and Maintain the Patients within the CPG Range?}

The number of reports evaluating the benefits of maintaining CKD patients within the proposed range is scant. More time between the application of the CPGs and measuring an objective effect on clinical outcome may be needed. Very recently, Barreto et al. [35] reported the results of a prospective 1-year follow-up study using bone morphometric analyses in patients submitted to two sequential bone biopsies. The authors observed that $88 \%$ of the patients having achieved the aimed range for $\mathrm{iPTH}$ developed low-turnover bone disease. Indeed, 10 out of 35 having the second biopsy and with iPTH level $>300$ $\mathrm{pg} / \mathrm{ml}$ presented a low-turnover bone disease. On the opposite, 3 out of the 13 having iPTH levels $<150 \mathrm{pg} / \mathrm{ml}$ presented high-turnover bone disease [35-37]. Therefore, (a) keeping the patients within the aimed range does not protect them from abnormal bone metabolism, and (b) iPTH levels may not be the good marker to adequately measure bone-remodeling in dialysis patients. 


\section{Final Summary}

Guidelines have been generated to help physicians with diagnostic and therapeutic strategies. Structuring the available knowledge and proposing evidence-based approaches to solve clinical problems should help practitioners to reach the final aim of improving care of the renal patients they have in charge. Many physicians, though, have felt concern about CPGs since they fear misuse. CPGs may be underlain by financial and other interests, or be used by public or private reimbursers to judge individual practices. Credible strategies to prevent this misuse are likely to reassure the medical community. Of particular importance to guarantee a flaw-free production of CPGs is harmonization of the grading of the evidence level of recommendations. Despite the initial problems and resistance to CPGs, the first results considering them in the evaluation of practice are coming. From their analysis it can be concluded that there is still room for improvement in adherence and that the percentage of patients fulfilling all the criteria stated in the recommendations remains small (5-20\%).

Finally, adherence to CPGs and CPRs is low, yes, but does it make any difference to outcomes that matter to patients? Retrospective studies analyzing the outcome as a function of adherence to CPGs do not satisfactorily answer this question, and epidemiologic studies of association are of limited assistance. Prospective controlled studies are needed to validate the essence of making CPGs and proposing them to the renal community, with the initial goals of improving care of patients with CKD. Correction of recommendations according to available and future controlled prospective studies should increase the likelihood for CPGs in achieving these initial goals.

\section{References}

1 Zoccali C, Abramowicz D, Cannata-Andia $\mathrm{JB}$, et al: European best practice quo vadis? From European Best Practice Guidelines (EBPG) to European Renal Best Practice (ERBP). Nephrol Dial Transpl 2008;23:21622166.

2 Uhlig K, MacLeod A, Craig J, Lau J, Levey AS, Levin A, Moist L, Steinberg E, Walker R, Wanner C, Lameire N, Eknoyan G: Grading evidence and recommendations for clinical practice guidelines in nephrology. A position statement from Kidney Disease: Improving Global Outcomes (KDIGO). Kidney Int 2006;70:2058-2065.

$>$ Eknoyan G, Levin A, Levin NW: Bone metabolism and disease in chronic kidney disease. Am J Kidney Dis 2003;42:1-201.

$\checkmark 4$ Vanbelleghem H, Vanholder R, Levin NW, Becker G, Craig JC, Ito S, Lau J, Locatelli F, Zoccali C, Solez K, Hales M, Lameire N, Eknoyan G: The kidney disease: improving global outcomes website: comparison of guidelines as a tool for harmonization. Kidney Int 2007;71:1054-1061.

5 Block GA, Hulbert-Shearon TE, Levin NW, Port FK: Association of serum phosphorus and calcium $\times$ phosphate product with mortality risk in chronic hemodialysis patients: a national study. Am J Kidney Dis 1998;31: 607-617.

-6 Ganesh SK, Stack AG, Levin NW, HulbertShearon T, Port FK: Association of elevated serum $\mathrm{PO}_{4}, \mathrm{Ca} \times \mathrm{PO}_{4}$ product, and parathyroid hormone with cardiac mortality risk in chronic hemodialysis patients. J Am Soc Nephrol 2001;12:2131-2138.

$\checkmark 7$ O'Neill WC: The fallacy of the calciumphosphorus product. Kidney Int 2007;72: 792-796.
$>_{8}$ Souberbielle JC, Boutten A, Carlier MC, Chevenne D, Coumaros G, Lawson-Body E, Massart C, Monge M, Myara J, Parent X, Plouvier E, Houillier P: Inter-method variability in PTH measurement: implication for the care of CKD patients. Kidney Int 2006; 70:345-350.

$\checkmark 9$ Friedman PA, Goodman WG: $\mathrm{PTH}_{1-84} /$ $\mathrm{PTH}_{7-84}$ : a balance of power. Am J Physiol Renal Physiol 2006;290:975-984.

10 Monge M, Shahapuni I, Oprisiu R, Esper NEI, Morinière P, Massy Z, Choukroun G Fournier A: Reappraisal of 2003 NKF-K/ DOQI guidelines for management of hyperparathyroidism in chronic kidney disease patients. Nat Clin Pract Nephrol 2006;2: 326-336.

11 Block GA, Klassen PS, Lazarus JM, Ofsthun N, Lowrie EG, Chertow GM: Mineral metabolism, mortality, and morbidity in maintenance hemodialysis. J Am Soc Nephrol 2004; 15:2208-2218

12 Ix JH, Quarles LD, Chertow GM: Guidelines for disorders of mineral metabolism and secondary hyperparathyroidism should not yet be modified. Nat Clin Pract Nephrol 2006;2: 337-339.

13 Block GA, Raggi P, Bellasi A, Kooienga L, Spiegel DM: Mortality effect of coronary calcification and phosphate binder choice in incident hemodialysis patients. Kidney Int 2007;71:438-441.

14 Suki WN, Zabaneh R, Cangiano JL, Reed J, Fischer D, Garrett L, Ling BN, Chasan-Taber S, Dillon MA, Blair AT, Burke SK: DCOR study (Dialysis Clinical Outcomes Revisited): effects of sevelamer and calcium-based phosphate binders on mortality in hemodialysis patients. Kidney Int 2007;72:1130-1137.
15 Tonelli M, Wiebe N, Culleton B, Lee H, Klarenbach S, Shrive F, Manns B: Systematic review of the clinical efficacy and safety of sevelamer in dialysis patients. Nephrol Dial Transplant 2007;22:2856-2866.

16 Fournier AE, Johnson WJ, Taves DR, Beabout JW, Arnaud CD, Goldsmith RS: Etiology of hyperparathyroidism and bone disease during chronic hemodialysis. J Clin Invest 1971;50:592-598.

17 Fournier AE, Arnaud CD, Johnson WJ, Taylor WF, Goldsmith RS: Etiology of hyperparathyroidism and bone disease during chronic hemodialysis. J Clin Invest 1971;50: 599-605.

$>18$ Argilés A, Kerr PG, Canaud B, Flavier JL, Mion C: Calcium kinetics and the long-term effects of lowering dialysate calcium concentration. Kidney Int 1993;43:630-640.

$>19$ Argilés A, Mion CM, Thomas M: Calcium balance and intact parathormone variations during haemodiafiltration. Nephrol Dial Transplant 1995;10:2083-2089.

20 Spasovski G, Gelev S, Masin-Spasovska J, Se$\lim$ G, Sikole A, Vanholder R: Improvement of bone and mineral parameters related to adynamic bone disease by diminishing dialysate calcium. Bone 2007;41:698-703.

21 Argilés A: Points to remember when selecting dialysate calcium concentration. Nephrol Dial Transplant 1995;10:451-454.

22 Moe SM, Cunningham J, Bommer J, Adler S, Rosansky SJ, Ureña-Torres P, Albizem MB, Guo MD, Zani VJ, Goodman WG, Sprague SM: Long-term treatment of secondary hyperparathyroidism with the calcimimetic cinacalcet $\mathrm{HCl}$. Nephrol Dial Transplant 2005;20:2186-2193. 
-23 Arenas MD, Alvarez-Ude F, Gil MT, Moledous A, Malek T, Nuñez C, Devesa R, Carretón MA, Soriano A: Implementation of 'K/ DOQI Clinical Practice Guidelines for Bone Metabolism and Disease in Chronic Kidney Disease' after the introduction of cinacalcet in a population of patients on chronic haemodialysis. Nephrol Dial Transplant 2007; 22:1639-1644.

-24 Gejyo F, Homma N, Suzuki Y, Arakawa M: Serum levels of $\beta_{2}$-microglobulin, as a new form of amyloid protein in patients undergoing long-term hemodialysis. N Engl J Med 1986;314:585-586.

-25 Van Ypersele de Strihou C, Jadoul M, Malghem J, Maldague B, Jamart J, The Working Party on Dialysis Amyloidosis: Effect of dialysis membrane and patient's age on signs of dialysis-related amyloidosis. Kidney Int 1991;39:1012-1019.

-26 Schwalbe S, Holzhauer M, Schaeffer J, Galanski M, Koch KM, Floege J: $\beta_{2}$-Microglobulin-associated amyloidosis: a vanishing complication of long-term hemodialysis? Kidney Int 1997;52:1077-1083.

-27 Cheung AK, Rocco MV, Yan G, Leypoldt JK, Levin NW, Greene T, Agodoa L, Bailey J, Beck GJ, Clark W, Levey AS, Ornt DB, Schulman G, Schwab S, Teehan B, Eknoyan G: Serum $\beta_{2}$-microglobulin levels predict mortality in dialysis patients: results of the HEMO study. J Am Soc Nephrol 2006;17:546-555.
28 Hoy T, Fisher M, Barber B, Borker R, Stolshek B, Goodman W: Adherence to K/DOQI Practice Guidelines for Bone Metabolism and Disease. Am J Manag Care 2007;13:620 625.

29 Noordzij M, Korevaar JC, Boeschoten EW Dekker FW, Bos WJ, Krediet RT, Netherlands Cooperative Study on the Adequacy of Dialysis (NECOSAD) Study Group: The Kidney Disease Outcomes Quality Initiative (K/DOQI) Guideline for Bone Metabolism and Disease in CKD: association with mortality in dialysis patients. Am J Kidney Dis 2005;46:925-932.

30 Rivera F, Sanchez de la Nieta MD, Anaya S, Carreno A, Vozmediano MC, Alcaide MP: Control del metanbolismo calcio-fosforo en hemodiálisis y su adcuacion a las guias $\mathrm{K} /$ DOQI 2003. Nefrologia 2006;26:351-357.

31 Arenas MD, Alvarez-Ude F, Gil MT, Soriano A, Egea JJ, Millán I, Amoedo ML, Muray S, Carretón MA: Application of NKF-K/DOQI Clinical Practice Guidelines for Bone Metabolism and Disease: changes of clinical practices and their effects on outcomes and quality standards in three haemodialysis units. Nephrol Dial Transplant 2006;21: 1663-1668.
32 Craver L, Marco MP, Martínez I, Rue M, Borràs M, Martín ML, Sarró F, Valdivielso JM, Fernández E: Mineral metabolism parameters throughout chronic kidney disease stages 1-5: achievement of K/DOQI target ranges. Nephrol Dial Transplant 2007;22: 1171-1176.

33 Wald R, Tentori F, Tighiouart H, Zager PG, Miskulin DC: Impact of the Kidney Disease Outcomes Quality Initiative (K/DOQI) Clinical Practice Guidelines for Bone Metabolism and Disease in a large dialysis network. Am J Kidney Dis 2007;49:257-266.

34 Ishani A, Solid CA, Weinhandl ED, Gilbertson DT, Foley RN, Collins AJ: Association between number of months below K/DOQI haemoglobin target and risk of hospitalization and death. Nephrol Dial Transplant 2008;23:1682-1689.

35 Barreto FC, Barreto DV, Moysés RM, Neves $\mathrm{KR}$, Canziani ME, Draibe SA, Jorgetti V, Carvalho AB: K/DOQI-recommended intact PTH levels do not prevent low-turnover bone disease in hemodialysis patients. Kidney Int 2008;73:771-777.

36 Nolan CR, McCarron DA: Lack of mortality benefit with sevelamer. Kidney Int 2008;73: 1093.

37 Suki WN: Response to 'Lack of mortality benefit with sevelamer'. Kidney Int 2008;73: 1093-1094. 